\title{
Partial Amino Acid Sequence of Cucumber Green Mottle Mosaic Virus Coat Protein ${ }^{\dagger}$
}

\author{
By Kotoku Kurachi, Gunki Funatsu, Masaru Funatsu \\ and Soh HIDAKA \\ Laboratory of Biochemistry, Faculty of Agriculture, Kyushu University, \\ Fukuoka, Japan \\ Received October 22, 1971
}

\begin{abstract}
Chymotryptic peptides of CGMMV* protein were separated by chromatography on a AG50W-X2 column. Tryptic peptides obtained before and chymotryptic peptides which contain basic amino acids were aligned to yield a partial amino acid sequence (residue 41 to 129 in the corresponding TMV protein) of the protein. Amino acid sequences of coat proteins of TMV group were compared and CGMMV protein showed some variations even in such sections as 87 to 94 or 113 to 122 , which is identical in the other coat proteins. Distributions of hydrophobicity in CGMMV, TMV, and HR proteins were found to be very similar each other in spite of fairly large difference in amino acid sequences. This suggests that the specific distribution of hydrophobicity in the primary structure would be significant for specific conformation of the protein which construct the rod-shaped virus particle.
\end{abstract}

In the preceding paper, ${ }^{11}$ we reported that CGMMV belongs to TMV group and is a strain least releated to TMV among viruses so far known to be in TMV group. As Inoue et $a l .^{2)}$ reported before, this virus is just similar in its shape (rod, $180 \cdots 3,000 \AA$ ) and other physico-chemical properties to TMV but different in its pathological properties. The amino acid composition of the protein is also most different from TMV ${ }^{11}$ These lead us to conclude that this virus protein is very good material for studying the relationship between the structure and the function of the protein. With the amino acid sequence of this protein, we will learn more essential structure to its function in virus particle.

\footnotetext{
+ Amino Acid Sequence of Cucumber Green Mottle Mosaic Virus Coat Protein. Part II.

* Abbreviations used: CGMMV, cucumber green mottle mosaic virus; TMV, tobacco mosaic virus (Vulgare); HR, Holmes ribgrass strain; TPCK, 1tosylamido-2-phenylethyl chloromethyl ketone.
}

In this paper, we report further study on amino acid sequence of the protein and discuss in relationship with its function.

\section{MATERIALS AND METHODS}

CGMMV protein. The coat protein was separated by the cold acetic acid method ${ }^{3}$ from the virus ${ }^{11}$ and was lyophilized.

Chymotrypsin and trypsin. These enzymes were purchased from Worthington Biochemical Corporation. Chymotrypsin was used without further purification. Trypsin was treated with TPCK prior to use.

Nagarse. This enzyme was purchased from Nagase Sangyo Co.

Other reagent. Phenylisothiocyanate and trifiuoroacetic acid were purchased from the Institute for Protein Research of Osaka University. Pyridine and benzene were of analytical grade. Hydrazine was purchased from Ishizu Chemical Industry Corp., and was redistilled prior to use. All other chemicals used were of reagent grade. 
Chymotryptic digestion of the protein. The suspension of the protein $(200 \mathrm{mg}$ ) in $10 \mathrm{ml}$ of water was adjusted to and maintained at $\mathrm{pH} 8.0$ with $1 \mathrm{~N} \mathrm{NaOH}$ at $38^{\circ} \mathrm{C}$ in the vessel of a Radiometer (Copenhagen, TTT1C) pH-stat. A $2 \mathrm{mg}$ aliquot of chymotrypsin which was dissolved in water was added at zero time and another same aliquot after $1 \mathrm{hr}$ of digestion. The digestion was stopped after $5.5 \mathrm{hr}$. The insoluble matter in the digest at $\mathrm{pH} 8$ was separated by centrifugation and the supernatant was lyophilized. The peptides were then chromatographed on an $\mathrm{AG} 50-\mathrm{X} 2$ column $(0.9 \times 150 \mathrm{~cm})$ equilibrated with the $0.2 \mathrm{M}$ pyridineacetic acid buffer ( $\mathrm{pH} 3.1$ ). The peptides were eluted with a double linear gradient of increasing $\mathrm{pH}$ and ionic strength. The gradients were: (gradient I) 600 $\mathrm{ml}$ of $0.2 \mathrm{M}$ pyridine-acetic acid ( $\mathrm{pH} 3.1$ ) followed by $600 \mathrm{ml}$ of $0.2 \mathrm{M}$ pyridine-acetic acid (pH 3.1) and $600 \mathrm{ml}$ of $2 \mathrm{M}$ pyridine-acetic acid (pH 5.0); (gradient II) $250 \mathrm{ml}$ of $2 \mathrm{M}$ pyridine-acetic acid ( $\mathrm{pH} 5.0$ ) and 250 $\mathrm{ml}$ of $2 \mathrm{M}$ pyridine-acetic acid ( $\mathrm{pH} 6.0$ ). The column

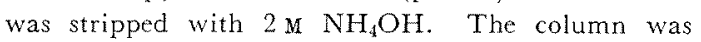
maintained at $38^{\circ} \mathrm{C}$ and the flow rate was $40 \mathrm{ml}$ per hour. The effluent was collected in $5.0 \mathrm{ml}$ fractions. The separation was monitored by ninhydrin color at $570 \mathrm{~m} /$ after alkaline hydrolysis and peptide-containing fractions were pooled accordingly. Sakaguchi reaction for arginine was also performed without the prior hydrolysis with alkali.

Digestion of peptides with nagarse or trypsin. A given amount of peptides was dissolved in $2 \sim 3 \mathrm{ml}$ of water and was adjusted to $\mathrm{pH} 8.0$ with $0.5 \mathrm{~N}$ $\mathrm{NaOH}$ or $1 \mathrm{~N} \mathrm{NH}{ }_{4} \mathrm{OH}$. A protease, approximately 20 of the peptide substrate by weight, was added and the mixture was stirred at $38^{\circ} \mathrm{C}$ for 2.5 to $3 \mathrm{hr}$. The $\mathrm{pH}$ of the mixture was maintained at $\mathrm{pH} 8.0$ throughout digestion by an occasional addition of alkaline solution. Sub-digests were fractionated on a Dowex $1 \times 2$ column $(1 \times 50 \mathrm{~cm})$ under almost the same conditions as those used for separation of tryptic peptides of the protein, ${ }^{13}$ except that the column was operated at room temperature. Paper chromatography was also used to separate some of the sub-digests (pyridine-butanol-acetic acid-water, $10: 15: 3: 12$, v/v), and high voltage paper electrophoresis at $\mathrm{pH} 6.5$ (pyridine-acetic acid-water, 10:0.4:90, v/v, 3,000 volts, 1 hr).

Other methods. Amino acid analysis of peptides was carried out with a Hitachi Amino Acid Analyzer, Model KLA 3B. Sequence determination of peptides by subtractive Edman degradation was performed according to the method of Konigsberg and Hill.4) Hydrolysis of peptides with $0.03 \mathrm{~N} \mathrm{HCl}$ was performed at $107^{\circ} \mathrm{C}$ for 16 to $20 \mathrm{hr}$ in an evacuated, sealed tube.

\section{RESULTS}

\section{Isolation of chymotryptic peptides}

The separation of the soluble chymotryptic peptides is shown in Fig. 1. Each fraction was pooled and examined for purity by paper chromatography. Impure fractions were purified by paper chromatography or preparative high voltage paper electrophoresis. Peptides which contain basic amino acids and gave overlaps between tryptic peptides are listed in Table I.

\section{Amino acid sequence of a chymotryptic peptide} $(C-13)$ containing a histidine residue

Asn-Ala-Thr-Lys-Arg-Asx-Asx-Asx-AlaSer-Thr-Ala-Ala-His-Asx-Asx-Ile-Leu-ProLeu-Leu

Since the tryptic peptide containing a histidine residue was difficult to get pure, peptide $\mathrm{C}-13$ was used to determine the amino acid sequence around the histidine residue. Tryptic subdigestion of $\mathrm{C}-13$ gave four peptides which were fractionated by a Dowex $1 \times 2$ column. The first peptide $(\mathrm{C}-13 \mathrm{~T}-1)$ contained lysine. The second peptide $(\mathrm{C}-13 \mathrm{~T}-2)$ contained lysine and arginine. Since the amino acid composition of these peptides were identical with those of the carboxyl-terminal portion of peptide $\mathrm{T}-10$, peptide $\mathrm{C}-13$ was found to be connected with peptide $\mathrm{T}-10$.

Since third and fourth peptides contained histidine and the amino acid compositions of these peptides were identical except arginine, these peptides were combined and further submitted to nagarse-digestion. The digest yielded four peptides which were fractionated by a Dowex $1 \times 2$ column. The sequence of each peptide obtained was partially determined, mainly by Edman degradation. Four rounds of Edman degradation of $\mathrm{C}-13 \mathrm{~T}$ - 


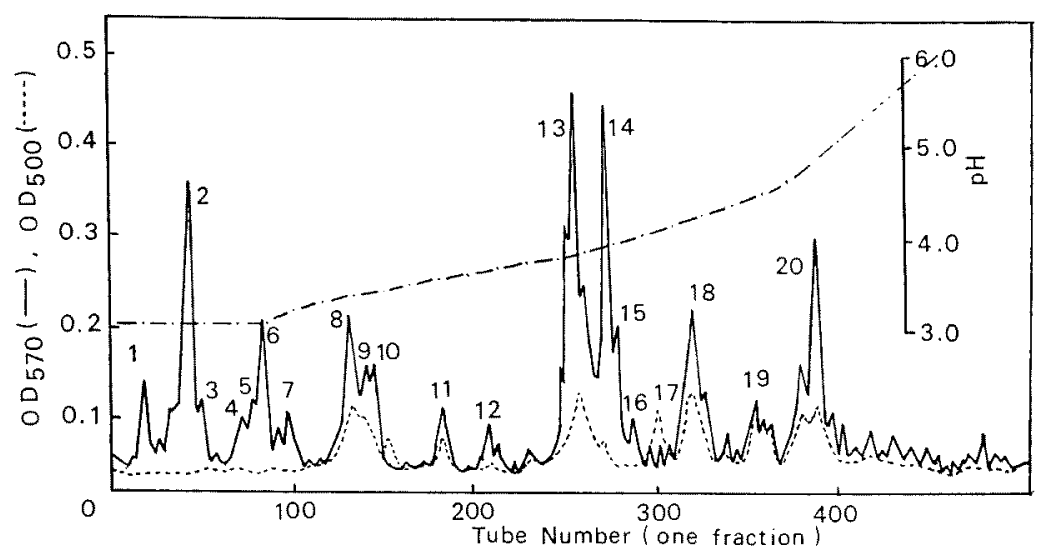

FIG. 1. Elution Profile of the Chymotryptic Peptide from CGMMV Protein on a $1.0 \times 150 \mathrm{~cm}$ Column of $\mathrm{AG} 50-\mathrm{X} 2$ at $38^{\circ}$.

The column was developed at $50 \mathrm{ml} / \mathrm{hr}$ with a double linear gradient of pyridine acetate as described in the text. Fractions of $5.0 \mathrm{ml}$ were collected and monitored by ninhydrin analysis after alkaline hydrolysis (solid line) and by Sakaguchi reaction (dotted line).

Table I. Amino Acid Compositions of Chymotryptic Peptidesal from CGMMV-Protein

\begin{tabular}{|c|c|c|c|c|c|c|c|c|c|c|c|c|c|}
\hline \multirow{2}{*}{$\begin{array}{l}\text { Peak } \\
\text { Amino acid }\end{array}$} & \multirow[t]{2}{*}{8} & \multirow[t]{2}{*}{9} & \multirow[t]{2}{*}{10} & \multirow[t]{2}{*}{11} & \multirow[t]{2}{*}{13} & \multirow[t]{2}{*}{14} & \multirow[t]{2}{*}{16} & \multicolumn{2}{|c|}{17} & \multirow[t]{2}{*}{18} & \multirow[t]{2}{*}{19} & \multicolumn{2}{|c|}{20} \\
\hline & & & & & & & & a & $b$ & & & a & $b$ \\
\hline Lys & 1.00 & & & 0.28 & 1.00 & 0.79 & 0.74 & 0.84 & 0.82 & & & & \\
\hline $\mathrm{His}$ & & & & & 0.84 & & & & & & & & \\
\hline Arg & 0.96 & 2.00 & 1.77 & 1.00 & 0.97 & & 1.00 & 1.17 & 2.00 & 1.45 & 0.92 & 1.00 & 1.22 \\
\hline Asp & 2.21 & 4.87 & 3.80 & 0.53 & 4.77 & & 2.21 & 2.26 & 1.78 & 1.96 & 1.00 & & 1.02 \\
\hline Thr & 2.64 & 1.56 & 1.14 & 1.68 & 1.56 & & 0.87 & 0.45 & 0.70 & & & & \\
\hline Ser & 4.75 & 3.60 & 3.80 & 2.83 & 1.52 & 1.05 & 1.10 & 1.17 & 2.12 & 1.17 & 0.94 & 1.29 & 2.50 \\
\hline Glu & 1.71 & 3.73 & 2.70 & 0.75 & 0.85 & & 0.92 & 1.00 & 1.36 & 0.70 & 1.00 & 0.71 & 1.16 \\
\hline Pro & & 2.43 & 1.83 & 0.93 & 1.08 & & & & 0.86 & 1.00 & 0.98 & & \\
\hline Gly & 0.68 & 2.13 & 1.52 & 2.49 & 1.56 & & 1.15 & 1.14 & 1.96 & & & & 0.46 \\
\hline Ala & 3.57 & 3.02 & 3.30 & 1.55 & 3.39 & 1.07 & 1.21 & 0.95 & 1.56 & 0.84 & 1.15 & & 2.10 \\
\hline Val & 0.94 & 1.08 & 1.16 & & & & & & & & & & \\
\hline Ile & 0.54 & 1.16 & 1.00 & 0.88 & 0.86 & & 0.54 & 0.95 & 1.34 & & & & 1.60 \\
\hline Leu & 0.61 & 2.39 & 2.00 & 2.14 & 2.40 & & 1.64 & 1.86 & 3.12 & & & & 1.76 \\
\hline Tyr & & & & & & & & & & & & & \\
\hline Phe & & & & 0.93 & & 1.00 & 0.54 & & 1.28 & 2.00 & 2.94 & & \\
\hline Yield 96 & 84 & 21 & c) & 4 & 56 & 7 & 17 & c) & 2 & 16 & 8 & 20 & 8 \\
\hline Purification ${ }^{b}$ ) & $\mathrm{P}$ & $\mathrm{P}$ & $\mathrm{P}$ & $\mathrm{P}$ & - & $\mathrm{P}, \mathrm{E}$ & - & P, E & $\mathrm{P}$ & $\mathrm{P}$ & $\mathrm{P}$ & $\mathrm{P}$ & $\mathrm{P}$ \\
\hline Overlap & & $\begin{array}{c}\mathrm{T} 9, \mathrm{Tl} \\
\mathrm{T} 10\end{array}$ & $\frac{\mathrm{T} 9, \mathrm{~T} 1}{\mathrm{~T} 10}$ & & $\begin{array}{l}\text { T } 10 \\
\text { Cl3 }\end{array}$ & & $\begin{array}{l}\mathrm{TP}-\mathrm{N}, d \\
\mathrm{~T} 6, \mathrm{~T} 4\end{array}$ & $\begin{array}{l}\mathrm{TP}-\mathrm{N}, d \\
\mathrm{~T} 6, \mathrm{~T} 4\end{array}$ & $\begin{array}{l}\mathrm{TP}-\mathrm{N}, d) \\
\mathrm{T} 6, \mathrm{~T} 4\end{array}$ & $\begin{array}{l}\mathrm{T} 4 \\
\mathrm{~T} 8\end{array}$ & $\begin{array}{l}\mathrm{T} 4 \\
\mathrm{~T} 8\end{array}$ & $\begin{array}{l}\mathrm{T} 6 \\
\mathrm{~T} 4\end{array}$ & $\begin{array}{l}\text { (T8, } \\
\text { T9) }\end{array}$ \\
\hline
\end{tabular}

a) In this table, only those peptides which contain basic amino acids and have possibilities to bridge tryptic peptides are summarized.

b) Abbreviations used are: $\mathrm{P}$, paper chromatography; $\mathrm{E}$, high voltage electrophoresis.

c) Not calculated.

d) N-Terminal tryptic peptide of the protein. 
Table II. Characterization of Peptide C-13

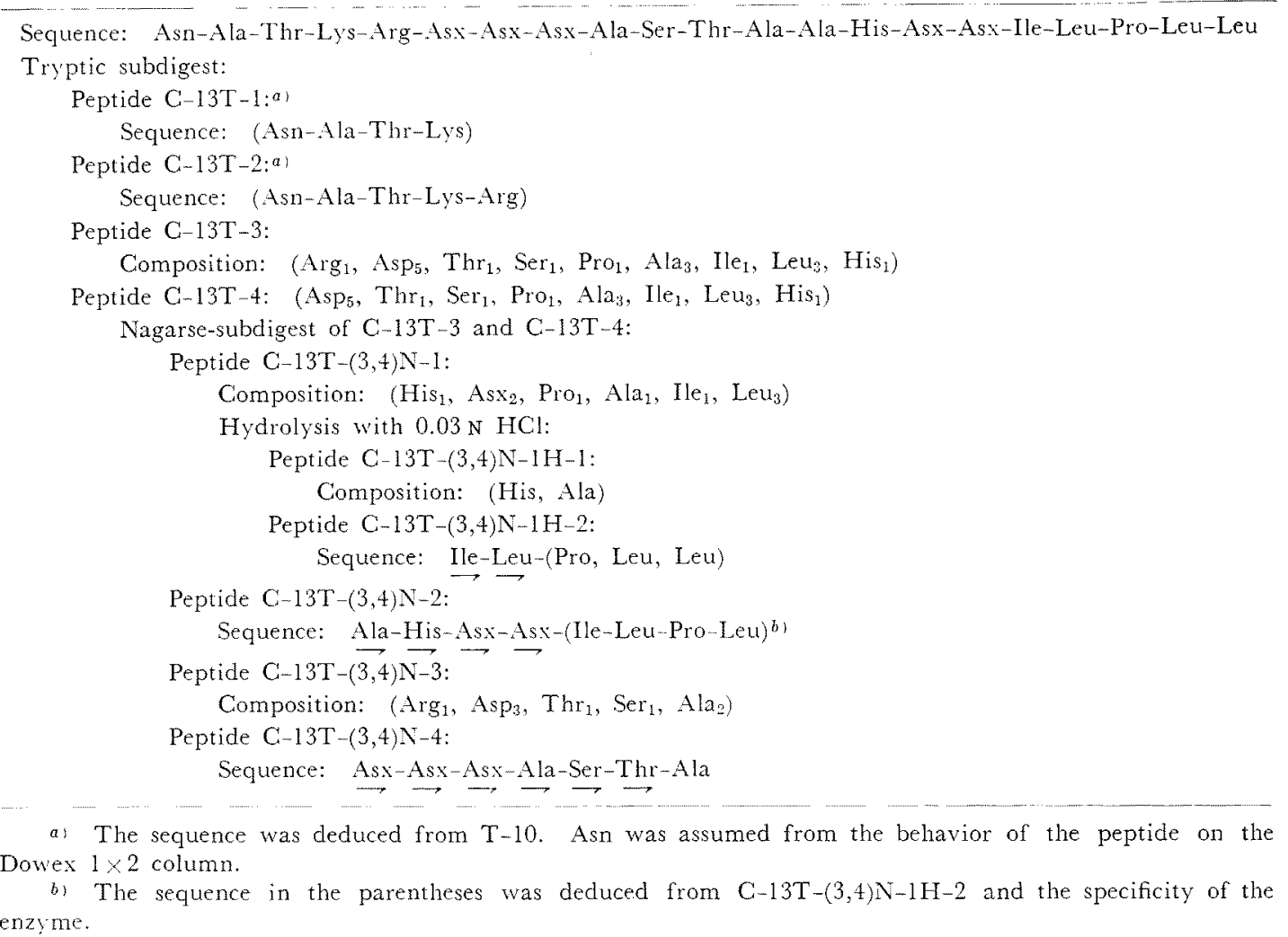

$(3,4) \mathrm{N}-2$ were accomplished before the remainder of the peptide was inexplicably lost. Then, C-13T-(3,4)N-1 was partially hydrolyzed with $0.03 \mathrm{~N} \mathrm{HGl}$ to yield two smaller fragments which were fractionated by high voltage paper electrophoresis. The routine method of Edman degradation of C-13T$(3,4) \mathrm{N}-1 \mathrm{H}-2$ was not accomplished again before the inexplicable loss of the remaining peptide in the water layer. After the failure of the Edman method was shown to be caused by high solubility of the peptide in benzene, the subsequent Edman degradations were performed by analyzing amino acid compositions of the remaining peptide dissolved in the benzene used for elimination of excess PTH. The results are summarized in Table II.

\section{Alignment of tryptic and chymotryptic peptides}

The alignment of tryptic and chymotryptic peptides which have been purified is shown in Fig. 2. The alignment was also performed to maximize the homology with TMV protein. In each line, the tryptic peptides are positioned below and the chymotryptic peptides above the sequence. Thus, the amino acid sequence of the portion, residue No. 41 to 129 of the corresponding TMV protein was determined. The positions of $T-2, T-3$ and $T-5$ were not yet determined directly.

\section{DISCUSSIONS}

As shown in Fig. 2, sequences of CGMMV and TMV proteins ${ }^{5}$ are similar in some respects. The locations of basic amino acids, 
40 50

Vulgare --GInG InAlaArgThrVa1ValGlnArgG InPheSerGluValTrpLysProSerProG 1nValThrValArg

CGMMV $\quad-(\stackrel{K}{K}$ AspalaglyLys) AspI leLeuArgG luS erLeuThrLeuglyLeuThrSerValAlaSerLeuAsnSerArg

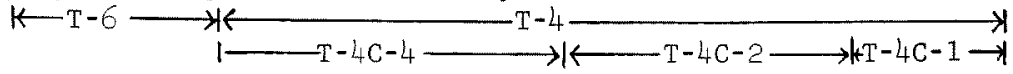

70

80

PheProAspSerAspPheLysVa1Tyr ArgTyrAsnAlaVa1LeuAspProLeuValThrAlaLeuLeu

$\longrightarrow \mathrm{C}-19 \mathrm{C}-18 \longrightarrow \mathrm{H}$

PheProAlaAsxGlxPhePheVa1TrpSerArgI leAlaAlaI leLeuSerAspLeuI leA laSerAsxLeu

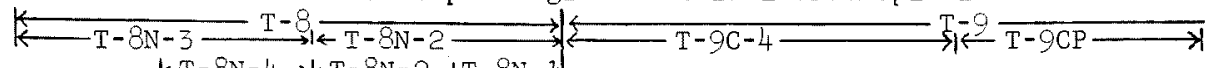

$k T-8 N-4 \rightarrow k T-8 N-2 \rightarrow k T-8 N-1$

90

100

GlyAlaPheAspThrArgAsnArgIleI legluValgluAsnglnA laAsnProThrThrAlagluThrLeu

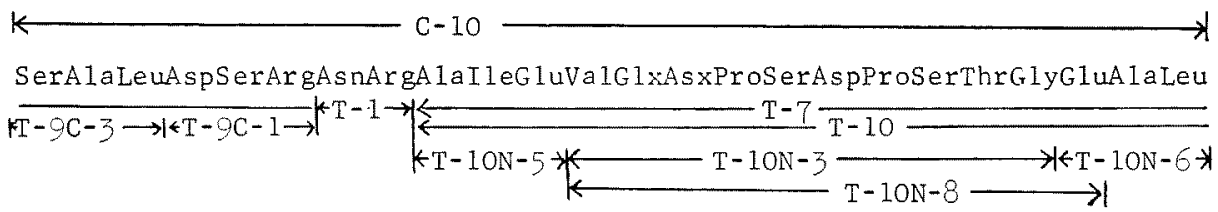

110

120

130

AspAlaThrArgArgValAspAspAlaThrValAlaIleArgSerAlaI leAsnAsnLeuIleValglu

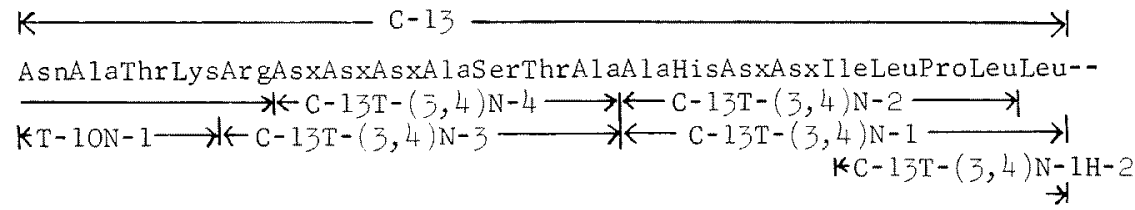

FIG. 2. Partial Sequence of CGMMV Protein.

Abbreviations used are: $\mathrm{T}$, tryptic peptide; $\mathrm{C}$, chymotryptic peptide; $\mathrm{H}$, peptide released by partial hydrolysis with $0.03 \mathrm{~N} \mathrm{HCl}$. The sequence in parentheses is not yet determined.

lysine and arginine, are beautifully coincident and the corresponding tryptic peptides are composed of almost the same number of amino acid residues in both proteins. As we reported before, " CGMMV protein is composed of 160 amino acid residues, which are two more residues than that of TMV protein, and one of the additional two residues is located between residue 70 and 71 of TMV protein as serine. The addition of amino acid like serine is genetically interesting besides the delection of amino acids in the protein of Holmes Ribgrass strain. ${ }^{6}$ In the structure of CGMMV protein, Ser-Arg appears four times. This repetition is also genetically interesting suggesting that the proteins may have evolved from shorter peptide chains as discussed by Smith et al. ${ }^{7)}$ on subtilisin Carlsberg. A comparison of the primary structures of coat proteins is shown in Fig. 3, in which the partial CGMMV protein sequence is added to the comparison originally proposed by Fraenkel-Conrat. ${ }^{8}$ It is seen that there are much fewer identical residues in the sequence of CGMMV protein than in the others. Portions, such as 87 to 94 and 113 to 122 as 
10

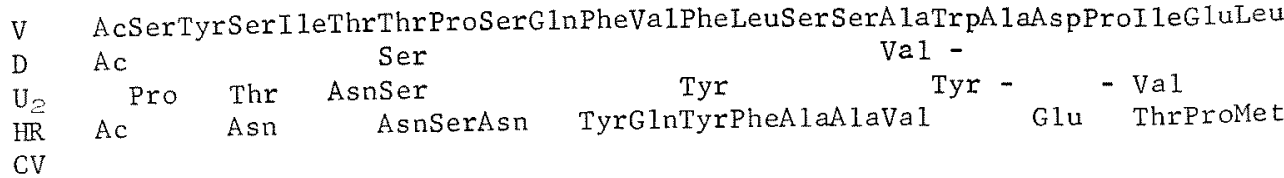

$\mathrm{CH}$

Ile HisHisLeuVa1 30 Leu 40 AlaLeuVa1 I leAsnLeuCysThrAsnA. IaLeuG lyAsnG InPheG 1 ThThG InG InA IaArgThrVa 1Va1G1nArg

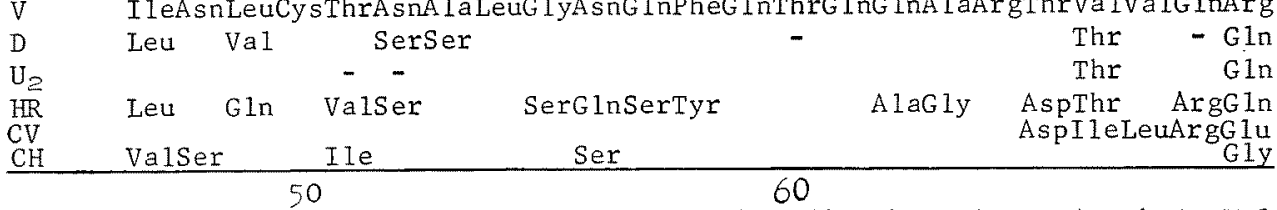

V G1nPheSerGInValTrpLysProSerProGlnValThrValArgPheProAspSerAspPheLysVal D Glu - Phe Ser GlyAspValTyr $\begin{array}{llrl}\mathrm{U}_{2} & \text { AlaAspAla } & \text { ValMet - } & \text { Tyr } \\ H R & \text { AlaAsnLeuLeuSerThrilevalAlaProAsngln } & \text { Thrgly Arg }\end{array}$ CV SerLeuThrLeuGlyLeuThrSerValAlaSerLeuAsnSer AlaAsxGlx Phe

\begin{tabular}{ccccc}
$\mathrm{CH}$ & Leu & AlaIle & Gly & Ser GlyGly \\
\hline 70 & 80 & 90
\end{tabular}

V TyrArgTyrAsnA lavalLeuAspProLeuValThrAlaLeuLeuglyAlaPheAspThrArgAsnArg

$\begin{array}{llll}\mathrm{D} & \text { Ile } & \text { Thr } \\ \mathrm{U}_{2} & \text { SerThr } & \text { Ile } & \text { AsnSer }\end{array}$

VRR ValAsserAlaValilelys Tyrglu MetLysser

CV Trp IleAla Ile SerAsp IleAlaserAsx Ser Leu Ser

$\mathrm{CH}$ Ser Ala

100

V IleIlegluValg luAsnglnA laAsnProThrThrA lagluThrLeuAspA laThrArgArgValAsp D - GlnSer $\mathrm{U}_{2} \quad$ Glx AsxAsxGlx Asx HR GlnThrGluGluGlnSerArg CV Ala GlxAsxProserAsp ValProI leAsxThrglxGlx - - -

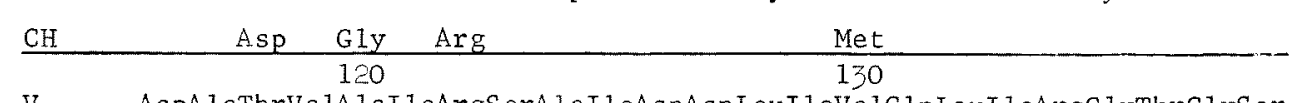

V AspAlaThrVa1AlaIleArgSerAlaIleAsnAsnLeuIleValGlnLeuI leArgG lyThrGlySer D - - ValAsn - Val - Leu $\mathrm{U}_{2} \quad-\quad$ Alaser AlaAsn Val - Met

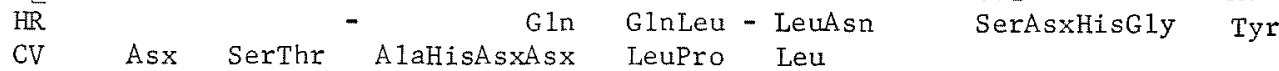

\begin{tabular}{|c|c|c|c|c|}
\hline & Gly & ValSer & Thr & Gly \\
\hline
\end{tabular}

V TyrAsnArgSerSerPheGlnSerSerSerGly LeuValTrpThrSerGlyProAlaThr

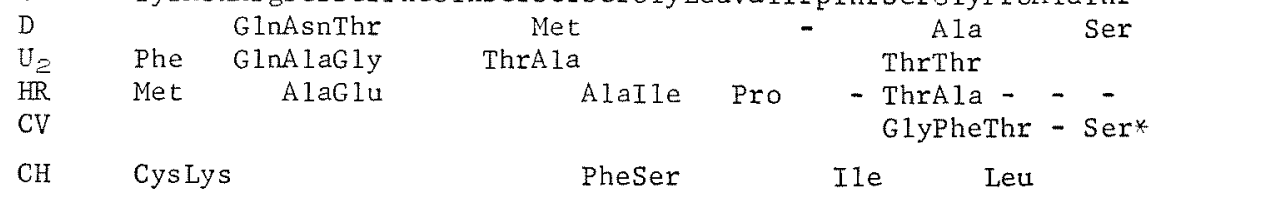

FIg. 3. The Amino Acid Sequence of Five Natural Strains of TMV and Mutant Exchange.

$\mathrm{V}$ stands for Vulgare, $\mathrm{D}$ for dahlemense, $\mathrm{U}_{2}$ for a mild strain isolated at the University of California, HR for Holmes ribgrass and CV for cucumber green mottle mosaic virus. CH represents amino acid replacements detected in chemically produced mutants. For all these sequences except CGMMV, refer to 1) and 8). Sequences identical to those in Vulgare protein were shown by dashed lines.

* C-Terminal sequence of CGMMV protein was determined by carboxypeptidase digestion and hydrazinolysis. 

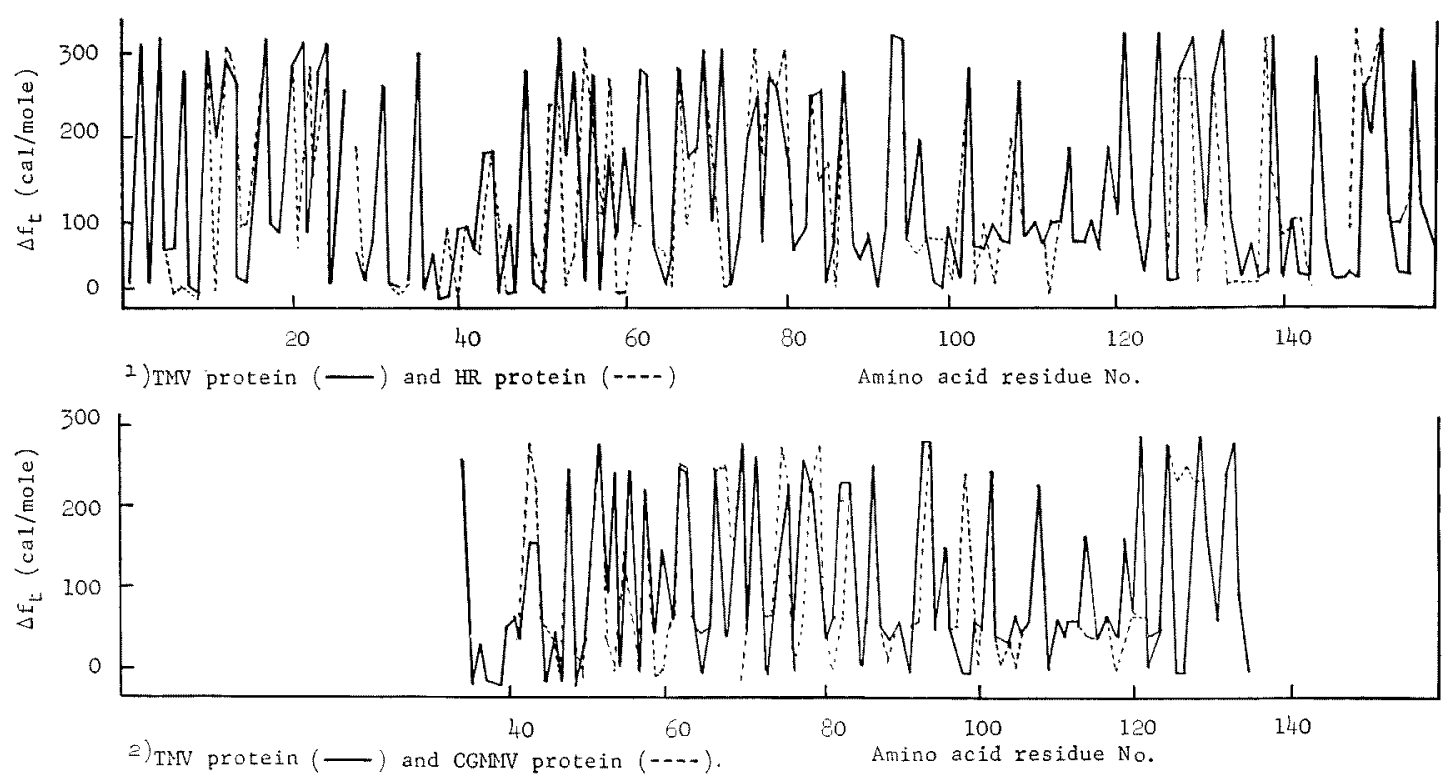

FIG. 4. Hydrophobicity Distribution in Primary Structure of TMV (Vulgare), HR and CGMMV Protein.

For CGMMV protein, partial sequence ( 42 to 129) was used.

well as cysteine residue, which have been believed to play some important role in functions of the subunit protein, were shown to permit some variation, while maintaining a functional conformation of the subunit protein. Residue 108-Leu to 112-Arg, about 22 residues from the carboxyl-terminus and 68-Lys of TMV protein are known to have immunological activities ${ }^{9,10)}$ and those corresponding parts in CGMMV protein are varied. Differences in immunological behavior of CGMMV from TMV could be partially due to these differences in amino acid sequence. In order to investigate the roles of variable regions in the sequence, distributions of hydrophobicity in the primary structure were compared in Fig. 4 , using the value $-1 f_{t}$, hydrophobicity of the side chain of each amino acid estimated by Tanford. ${ }^{11}$ It is apparent that patterns of hydrophobicity distribution in the primary structures of these proteins are similar to each other in spite of the great differences in their amino acid sequences. Generally, the regions with high hydrophobocity and that with low hydrophobicity alternate except for the section, residue 110 to 123 , that is composed of amino acids with comparatively low hydrophobicity. Therefore, the similarity in the hydrophobicity distribution appears to be important in the relationship between the sequence and the specific conformation of the protein. The specific distribution of hydrophobicity in the sequence would be necessary for maintaining a specific conformation of the subunit protein that is necessary for constructing the rod shaped virus particle. ${ }^{12}$ This hypothesis may be proved valid when a crystallographic structure determination of TMV protein is done.

\section{REFERENCES}

1) K. Kurachi, G. Funatsu and M. Funatsu, Agr. Biol. Chem., 36, 937 (1972).

2) T. Inoue, N. Inoue, M. Aso and K. Mitsuhata, Nogaku Kenkyu, 51, 175 (1967). 
3) H. Fraenkel-Conrat, Virology, 4, 1 (1957).

4) W. Konigsberg and R.J. Hill, J. Biol. Chem., 237, 2547 (1962).

5) G. Funatsu, A. Tsugita and H. Fraenkel-Conrat, Arch. Biochem. Biophys., 105, 25 (1964).

6) H. G. Wittmann, Z. Naturforsch., 206, 1213 (1965).

7) E. L. Smith, R. J. Delange, W. H. Evans, M. Landon and F. S. Markland, J. Biol. Chem., 243, 2184 (1968).
8) H. Fraenkel-Conrat, "Molecular Basis of Virology," ed. by H. Fraenkel-Conrat, ACS monograph, 1968, p. 134.

9) F. A. Anderer and H. D. Schlumberger, Biochim. Biophys. Acta, 115, 222 (1966).

10) J. D. Young, E. Benjamini and C. Y. Leung, Biochemistry, 7, 1455 (1967).

11) C. Tanford, J. Am. Chem. Soc., 84, 4240 (1962).

12) F. A. Anderer, Z. Naturforsch., 146, 642 (1959). 